\title{
ANALISIS TINGKAT KEUNTUNGAN DAN TITIK IMPAS USAHA PEMBUATAN IKAN LAIS SALAI DI DESA TANAH ABANG KECAMATAN BATANG HARI LEKO KABUPATEN MUSI BANYUASIN
}

\author{
Reshi Wahyuni $^{1, a}$, Fitra Mulia Jaya ${ }^{2}$, dan Nurlaili F. Gultom ${ }^{3}$ \\ ${ }^{1,3)}$ Sekolah Tinggi Ilmu Pertanian Sriwigama, \\ ${ }^{2)}$ Fakultas Perikanan Universitas PGRI Palembang \\ Jl. Demang IV-Demang Lebar Daun Lorok Pakjo Palembang Sumatera Selatan \\ Tel/Faks: +62711374146/Hp. 082177807889 \\ Email : reshiwahyuni@yahoo.co.id
}

\begin{abstract}
Abstrak
Tujuan dari penelitian ini adalah : 1) Mendeskripsikan teknik pengolahan ikan lais salai 2).Menganalisis tingkat keuntungan usaha pengolahan ikan lais salai. 3) Menganalisis titik impas usaha pengolahan ikan lais salai di Desa Tanah Abang Kecamatan Batanghari Leko Kabupaten Musi Banyuasin. Penelitian ini dilaksanakan di Desa Tanah Abang Kecamatan Batanghari Leko KabupatenMusi Banyuasin.Penelitian ini dilaksanakan pada bulan September sampai Oktober 2017. Metode yang digunakan dalam penelitian ini adalah metode studi kasus, dengan meneliti secara mendalam pengrajin ikan lais salai sebagai satuan kasus.Metode penarikan contoh dalam penelitian ini adalah metode sensus. Hasil penelitian menunjukkan bahwa rata-rata pendapatan usaha pengolahan ikan salai per periode adalah sebesar Rp. 6.367.740 dengan $\mathrm{RC}$ ratio sebesar 2,06. RC ratio pada usaha pengolahan ikan lais salai mempunyai nilai yang lebih besar dari satu. Hal ini berarti bahwa usaha pengolahan ikan lais salai menguntungkan. Usaha pengolahan ikan lais salai mengalami break even point atau berada pada titik impas yaitu tidak mendapatkan keuntungan dan tidak menderita kerugian jika penerimaan yang diperoleh sebesar Rp. 1.013.269,23 / periode produksi, produksi 6,34 kg /periode produksiatau harga jual sebesar $\mathrm{Rp} .72 .721,60$ /kg.
\end{abstract}

Kata Kunci : Ikan Lais, Salai, Tingkat keuntungan, Titik impas 


\section{PENDAHULUAN}

Sektor perikanan sebagai salah satu pendukung sektor ekonomi memiliki peran dalam pembangunan ekonomi nasional, yaitu memberikan nilai tambah dan mempunyai nilai strategis, serta dapat memberikan manfaat finansial maupun ekonomi, khususnya dalam penyediaan pangan protein, perolehan devisa, dan penyediaan lapangan kerja. Menurut Khairuman dan Amri (2011), produksi perikanan Indonesia tahun 2010 mencapai 10,83 juta ton atau naik 10,29 persen dibandingkan dengan tahun 2009 sebanyak 9,82 juta ton. Sampai tahun 2014 produksi ikan ditargetkan mencapai 22,39 juta ton dan sekitar 16,89 juta ton di antaranya merupakan hasil budidaya. Target ini juga sejalan dengan terus meningkatnya tingkat konsumsi masyarakat Indonesia terhadap ikan.

Pemanfaatan sumberdaya ikan tidak akan menghasilkan manfaat serta nilaiekonomis yang tinggi apabila tidak diikuti dengan kegiatan usaha pengolahan dan pemasaran yang baik. Untuk mendorong terciptanya peningkatan pemanfaatan sumberdaya ikan yang optimal dan sekaligus memberikan nilai ekonomis yang tinggi, perlu dilakukan kegiatan pengolahan produk hasil perikanan yang berkelanjutan. Pengembangan pengolahan ikan ini diharapkan mampu meningkatkan nilai tambah (value added) dan menciptakan variasi (ragam) produk sehingga segmen pasar lebih luas serta mampu menyerap tenaga kerja. Proses pengolahan ikan dapat dilakukan dengan berbagai cara seperti: penggaraman, pengeringan, pemindangan, pengasapan, fermentasi, pengolahandengan suhu rendah, pengolahan dengan suhu tinggi dan pengolahan hasil sampingan (Adawyah 2007).

Pengolahan ikan dengan berbagai cara dan rasa akan menyebabkan orang tertarik untuk mengkonsumsi ikan lebih banyak. Menurut Adawyah (2007), ikan asap merupakan cara pengawetan ikan dengan menggunakan asap yang berasal dari pembakaran kayu atau bahan organik lainnya. Ikan asap juga bisa jadi komoditas bisnis yang cukup menjanjikan apabila diolah dan dibumbui dengan cita rasa yang baik. Pengasapan ini merupakan kombinasi dari penggaraman, pemanasan dan pembubuhan zat-zat kimia yang berasal dari asap, yaitu senyawa aldehid, fenol dan asamasam yang bertujuan untuk membunuh bakteri, merusak aktifitas enzim, mengurangi kadar air dan menyerap berbagai senyawa kimia yang berasal dariasap. Selain itu, pengasapan juga dapat memberi rasa lezat dan aroma yang khas (Moeljanto, 1992).

Sebagian besar penduduk Desa Tanah Abang Kecamatan Batanghari Leko Kabupaten Musi Banyuasin bermata pencaharian sebagai petani karet dan nelayan. Namun karena turunnya harga karet membuat sebagian penduduk mencari alternatif tambahan pendapatan untuk memenuhi kebutuhan hidup keluarganya. Salah satu usaha yang dilakukan adalah pengolahan ikan lais salai yang bahan bakunya berasal dari perairan di daerah tersebut.Oleh karena itu yang menarik untuk diketahui pada penelitian ini adalah teknik pengolahan, tingkat keuntungan dan titik impas usaha pengolahan ikan lais salai di Desa Tanah Abang Kecamatan Batanghari Leko Kabupaten Musi Banyuasin.

\section{METODE PENELITIAN}

Penelitian ini dilaksanakan di Desa Tanah Abang Kecamatan Batanghari Leko Kabupaten Musi Banyuasin. Penelitian ini dilaksanakan pada bulan September sampai Oktober 2017. Penentuan lokasi dilakukan dengan sengaja (Purposive) dengan pertimbangan bahwa daerah ini terdapat pengrajin ikan lais salai. Metode yang digunakan dalam penelitian ini adalah metode studi kasus, dengan meneliti secara mendalam pengrajin ikan lais salai sebagai satuan kasus.Data yang dikumpulkan terdiri dari data primer dan data skunder. Data primer dilakukan melalui wawancara langsung dengan petani contoh menggunakan kuisioner yang telah disiapkan terlebih dahulu, sedangkan data sekunder diperoleh dari intansi terkait yang ada di Desa Tanah Abang Kecamatan Batanghari Leko Kabupaten Musi Banyuasin dan literatur yang berhubungan dengan penelitian ini.

Metode penarikan contoh dalam penelitian ini adalah metode sensus yaitu dengan mengambil keseluruhan populasi pengrajin ikan lais salai yang ada di Desa Tanah Abang Kecamatan Batanghari Leko Kabupaten Musi Banyuasin. Data yang dikumpulkan terdiri dari data primer dan data sekunder.Data primer dikumpulkan melalui wawancara langsung dengan petani contoh disertai dengan daftar pertanyaan yang telah dipersiapkan terlebih dahulu. Data primer yang dikumpulkan antara lain : identitas petani dan keluarganya, jumlah kolam, tenaga kerja yang mengelola usaha ikan lais salai, biaya-biaya yang dikeluarkan untuk proses produksi, penerimaan dan pendapatan usaha pengolahan ikan lais salai. Sedangkan data sekunder didapat dari dinas atau instansi- 
instansi atau badan yang berkaitan de.ngan penelitian ini.

Data yang diperoleh dari lapangan terlebih dahulu diolah secara tabulasi, lalu dianalisis kemudian dibahas secara deskriptif. Untuk permasalahan pertama diselesaikan dengan menggunakan perhitungan sebagai berikut :

Keterangan :

$$
\begin{aligned}
\mathrm{Pn} & =\mathrm{Pr} \times \mathrm{Hj} \\
\mathrm{Bp} & =\mathrm{Bt}+\mathrm{Bv} \\
\mathrm{Pd} & =\mathrm{Pn}-\mathrm{Bp}
\end{aligned}
$$

$$
\begin{aligned}
\mathrm{Pn} & =\text { Penerimaan }(\mathrm{Rp} / \mathrm{kg}) \\
\mathrm{Pr} & =\text { Produksi }(\mathrm{Kg} / \mathrm{mp}) \\
\mathrm{Hj} & =\text { Harga Jual }(\mathrm{Rp} / \mathrm{kg}) \\
\mathrm{Bp} & =\text { Biaya Produksi }(\mathrm{Rp} / \mathrm{mp}) \\
\mathrm{Bt} & =\text { Biaya Tetap }(\mathrm{Rp} / \mathrm{mp}) \\
\mathrm{Bv} & =\text { Biaya Variabel }(\mathrm{Rp} / \mathrm{mp}) \\
\mathrm{Pd} & =\text { Pendapatan }(\mathrm{Rp} / \mathrm{mp})
\end{aligned}
$$

Kemudian untuk menganalisis tingkat keuntunganusaha tersebut dinyatakan melalui $\mathrm{RC}$ ratio (Revenue cost) atau dikenal sebagai perbandingan antara penerimaan usahatani dengan total biaya produksi yang dapat diukur dari :

$$
\mathrm{RC} \text { ratio }=\frac{\text { Penerimaan }}{\text { Biaya Produksi }}
$$

Dimana :

Jika $\mathrm{RC}$ ratio > 1, maka usahatani dinyatakan menguntungkan

Jika $\mathrm{RC}$ ratio $=1$, maka usahatani dinyatakan tidak untung dan tidak rugi

Jika $\mathrm{RC}$ ratio $<1$, maka usahatani dinyatakan tidak menguntungkan

Analisis yang digunakan untuk menjawab tujuab kedua adalah analisis titik impas (Break Even Point) usaha pengolahan ikan lais salai. Menurut Suratiyah (2015) selama proses produksi atau secara metematis dapat dirumuskan sebagai berikut:

$$
\text { 1. BEP Penerimaan }=\frac{\mathrm{Btp}}{\frac{1-\mathrm{Bv}}{\mathrm{Py} \cdot \mathrm{Hy}}}
$$

\section{BEP Produksi (kg)}

$$
=\frac{\text { Btp }}{\text { Hy }- \text { Bvr }}
$$

3. BEP Harga $(\mathrm{Rp} / \mathrm{kg})=$

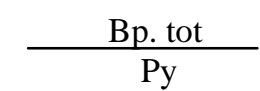

Dimana :

Btp = Biaya tetap $(\mathrm{Rp} / \mathrm{kg} / \mathrm{pp})$

$\mathrm{Bv} \quad=$ Biaya variabel $(\mathrm{Rp} / \mathrm{kg} / \mathrm{pp})$

Py = Produksiikan lais salai $(\mathrm{Kg})$

Hy $\quad$ = Harga ikan lais salai $(\mathrm{Rp} / \mathrm{kg})$

Bvr = Biaya variabel rata-rata

Bp.tot = Biaya produksi total

\section{HASIL DAN PEMBAHASAN}

\section{Sejarah Berdirinya Usaha Pembuatan Ikan Lais Salai}

Usaha pembuatan ikan lais salai di Desa Tanah Abang telah lama dilakukan namun pada saat itu pembuatan ikan salai hanya untuk memenuhi kebutuhan rumah tangga saja. Pada tahun 2000 masyarakat mulai mengembangkan usaha pembuatan ikan salai secara komersiil. Ide usaha dimulai dengan studi banding kegiatan usaha pembuatan ikan salai ditempat lain, lalu kemudian mereka mencobanya. Dari hasil uji coba ini, ternyata mereka berhasil dan menjadikan usaha ini sebagai salah satu sumber penghasilan. Saat ini terdapat enam orang pengrajin di Desa Tanah Abang.

Tempat penyalaian atau tempat pengasapan ikan salai berdampingan atau berdekatan dengan rumah pengrajin. Dalam hal permodalan, pengrajin mengeluarkan modal sendiri dan tenaga kerja yang digunakan adalah tenaga kerja dalam keluarga ataupun tenaga kerja harian. Bahan baku ikan tersebut berasal dari hasil tangkapan sendiri di sungai maupun membeli dari para nelayan ataupun pedagang yang menjual ikan. Proses pembuatan ikan salai ini masih bersifat tradisional yaitu dengan menggunakan drum sebagai tungku pengasapan dan bahan bakar yang digunakan adalah kayu karet. Dalam satu minggu pengrajin melakukan dua sampai tiga kali kegiatan produksi.

\section{Karakteristik Pengrajin Ikan Lais Salai}

Karakteristik pengrajin merupakan ciri khas yang melekat pada diri pengrajin yang berhubungan dengan berbagai aspek kehidupan sosial dan lingkungan mereka. Pada penelitian

\begin{tabular}{|c|c|c|c|}
\hline No & Umur & $\begin{array}{l}\text { Jumlah } \\
\text { (orang) }\end{array}$ & Persentase (\%) \\
\hline 1. & $21-30$ & 2 & 33,33 \\
\hline 2. & $31-40$ & 1 & 16,67 \\
\hline 3. & $41-50$ & 1 & 16,67 \\
\hline 4. & $51-60$ & 2 & 33,33 \\
\hline \multicolumn{2}{|c|}{ Jumlah } & 6 & 100 \\
\hline
\end{tabular}
ini, karakteristik petani yang diamati meliputi umur, tingkat pendidikan formal, dan jumlah anggota rumah tangga

a. Umur

Umur merupakan salah satu faktor yang penting bagi pengrajin untuk melakukan kegiatan usahanya. Pengrajin yang memiliki umur relatif muda mempunyai tenaga yang lebih kuat untuk melakukan kegiatan usahanya, sedangkan pengrajin yang memiliki umur relatif tua cenderung lebih lemah melakukan kegiatan usahanya. Karakteristik pengrajin berdasarkan umur dapat dilihat pada Tabel 1. 
Salah satu indikator dalam menentukan produktivitas kerja dalam melakukan pengembangan usaha adalah tingkat umur, dimana umur petani yang berusia relatif muda lebih kuat bekerja, cekatan, mudah menerima inovasi baru, tanggap terhadap lingkungan sekitar bila dibandingkan tenaga kerja yang sudah memiliki usia yang relatif tua sering menolak inovasi baru (Soekartawi, 2001). Berdasarkan tabel 1 di atas dapat dilihat bahwatingkat umur petani cukup beragam yaitu berkisar antara 21-30 tahun sampai 51-60 tahun.Penyebarannya merata yaitu untuk kisaran 21-30 tahun dan 51-60 tahun sebanyak $33,33 \%$ sedangkan kisaran 31-40 tahun dan 41-50 tahun sebanyak 16,67 \%.

\section{b. Pendidikan}

Tingkat pendidikan menjadi faktor penting terhadap pengelolaan usaha ikan lais salai. Pengrajin yang memiliki tingkat pendidikan tinggi biasanya memiliki wawasan pengetahuan yang luas mengenai usaha dibandingkan pengrajin yang memilliki tingkat pendidikan rendah. Tingkat pendidikan pengrajin dapat dilihat pada Tabel 2.

Tabel 2. Tingkat Pendidikan Petani

\begin{tabular}{cccc}
\hline No & Umur & Jumlah (orang) & Persentase \\
\hline 1. & SD & 2 & 33,33 \\
2. & SMP & 3 & 50 \\
3. & SMA & 1 & 16,67 \\
\hline \multicolumn{2}{c}{ Jumlah } & $\mathbf{6}$ & $\mathbf{1 0 0}$ \\
\hline
\end{tabular}

Berdasarkan tabel 2 tingkat pendidikan petani di wilayah penelitian sangat beragam. Tingkat pendidikan SMP merupakan tingkat pendidikan petani yang tertinggi, yaitu sebesar $50 \%$, sedangkan tingkat pendidikan SMA merupakan tingkat pendidikan petani terendah, yaitu hanya sebanyak 16,67\%.

\section{c. Jumlah Anggota Keluarga}

Jumlah anggota keluarga merupakan karakter yang menunjukkan banyaknya jumlah anggota yang masih menjadi beban tanggungan kepala keluarga. Selain itu pengrajin yang mempunyai jumlah anggota keluarga yang besar merupakan sumber tenaga kerja yang besar bagi kegiatan usahanya sehingga pengrajin dapat mengurangi kebutuhan tenaga kerja dari luar keluarga untuk mengelola kegiatan usahanya. Karakteristik pengrajin berdasarkan jumlah anggota keluarga dapat dilihat pada Tabel 3.

Tabel 3. Jumlah Anggota Keluarga Pengrajin

\begin{tabular}{cccc}
\hline No & Umur & Jumlah (orang) & Persentase \\
\hline 1. & 2 & 2 & 33,33 \\
2. & 3 & 1 & 16,67 \\
3. & 4 & 2 & 33,33 \\
4. & 5 & 1 & 16,67 \\
\hline \multicolumn{2}{c}{ Jumlah } & $\mathbf{6}$ & $\mathbf{1 0 0}$ \\
\hline
\end{tabular}

Berdasarkan tabel 3 jumlah anggota keluarga pengrajin beragam. Jumlah anggota keluarga pengrajin yang tertinggi adalah berjumlah 2 dan 4orang yaitu masing-masing sebesar $33,33 \%$, sedangkan jumlah terendah anggota keluarga petani adalah 3 dan 5 orang atau sebesar $16,67 \%$.

\section{Teknik Pengolahan Ikan Lais Salai}

Proses pembuatan ikan segar menjadi ikan salai di Desa Tanah Abang dilakukan secara tradisional dengan menggunakan metode pengasapan panas langsung, yaitu menggunakan asap dari kayu bakar sebagai sumber panas. Kayu bakar yang digunakan pengolah di desa ini adalah jenis kayu keras yang ada disekitar Desa Tanah Abang, seperti kayu pelangas, dan kayu batang karet. Kayu bakar didapatkan dengan cara mengambil kayu batang karet yang sudah mati di kebun karet milik sendiri ataupun dari para pengumpul kayu bakar dengan harga beli Rp 50.000,00 per keranjang. Adapun proses pembuatan ikan salai yang dilakukan yaitu terdiri dari persiapan bahan, pengeringan, pengasapan dan pengemasan

\section{a. Persiapan Bahan}

Ikan mentah yang akan disalai terlebih dahulu dilakukan penyiangan dan pencucian, kemudian ikan disortir menurut ukurannya. Selanjutnya ikan ditimbang untuk mengetahui berapa banyak ikan yang akan di salai tersebut. Setelah dicuci kemudian dimasukkan ke dalam baskom dan dilakukan penggaraman dan selanjutnya ikan ditiriskan dengan cara diletakkan di atas para - para (kawat pemanggang).

\section{b. Pengeringan}

Proses pengeringan dilakukan setelah ikan digarami. Ikan yang sudah digarami diletakkan di atas para - para atau ditempat pengasapan yang panas. Dengan pemanasan ini, air dalam daging ikan terutama lapisan permukaannya akan menguap sehingga ikan menjadi kering dan semakin awet. Proses pengeringan yang terjadi memungkinkan lapisan permukaan daging menyerap asap, yang terdiri dari partikel - partikel sangat halus. Selama proses pengeringan dilakukan persiapan untuk penyalaian.

\section{c. Proses Pengasapan Ikan Salai}

Sebelum penyalaian ikan dilakukan, terlebih dahulu hidupkan api pada kayu bakar dengan cara menyiram kayu bakar dengan minyak tanah, lalu disulut dengan api. Biarkan dulu api menyala sampai keadaan nyala api stabil (api sudah kecil), baru ikan - ikan diatas salayan ditaruh diatas tempat pengasapan atau penyalaian dan ditutup dengan seng agar asap kayu tidak menyebar dan meresap dikulit ikan. 
Selama proses penyalaian berlangsung, ikan ikan dibolak balik agar panas dan asap merata pada kedua sisi ikan sampai kering. Lama proses pengasapan berlangsung kurang lebih 34 jam atau sampai ikan sudah berwarna kuning atau coklat keemasan. Setelah itu api dipadamkan dan ikan - ikan dibiarkan sampai dingin.

\section{d. Pengemasan (Packaging) Produk}

Ikan - ikan hasil penyalaikan selanjutnya diangkat dari penyalaian, lalu kemudian dikemas dan siap dipasarkan. Ikan - ikan hasil penyalaian masih dikemas secara sederhana dalam kardus. Pemasaran ikan salai dilakukan baik di dalam Desa Tanah Abang maupun dijual ke pedagang pengumpul di pasar Sekayu.

\section{Analisis Tingkat Keuntungan Usaha}

\section{Pengolahan Ikan Lais Salai}

Untuk menganalisis berapa besar tingkat keuntungan yang diperoleh dari usaha pembuatan ikan salai maka perlu dihitung terlebih dahulu biaya - biaya yang harus dikeluarkan yang terdiri dari biaya tetap dan biaya variabel. Biaya tetap merupakan biaya yang sifatnya tetap dan tidak tergantung dengan jumlah produksi dan mengalami penyusutan nilai tiap periode produksi. Biaya variabel merupakan biaya yang sifat berubah dengan berubahnya produksi yang dihasilkan. Perhitungan periode produksi dalam penelitian ini dihitung selama satu bulan. Adapun rata-rata biaya tetap dan biaya variabel yang dikeluarkan dalam pengolahan ikan lais salai di daerah penelitian adalah sebagai berikut :

\section{a. Biaya tetap}

Biaya tetap yang dikeluarkan oleh pengrajin dalam pengolahan ikan lais salai terdiri dari biaya penyusutan drum, baslom, pisau, kawat pemanggang dan timbangan. Rincian rata-rata biaya penyusutan alat dapat dilihat pada Tabel 4

Tabel 4. Biaya Penyusutan Alat Usaha Pengolahan Ikan Lais Salai

\begin{tabular}{clcc}
\hline No & Uraian & $\begin{array}{c}\text { B.peny. alat } \\
\text { (Rp/periode) }\end{array}$ & $\begin{array}{c}\text { Persentase } \\
(\mathbf{\%})\end{array}$ \\
\hline 1. & Drum & 300.000 & 55,94 \\
2. & Baskom & 112.520 & 20,98 \\
3. & Pisau & 26.240 & 4,89 \\
4. & Kawat & 67.500 & 12,59 \\
& pemanggang & & \\
5. & Timbangan & 30.000 & 5,60 \\
\hline \multicolumn{2}{l}{ Jumlah } & $\mathbf{5 3 6 . 2 6 0}$ & $\mathbf{1 0 0}$ \\
\hline
\end{tabular}

Berdasarkan tabel 4, rata - rata biaya penyusutan alat yang dikeluarkan pengrajin dalam usaha pengolahan ikan salai adalah sebesar Rp. 536.260 untuk penyusutan drum sebesar Rp 300.000, baskom sebesar Rp 112.520, pisau sebesar Rp 26.240, kawat pemanggang sebesar Rp 67.500 serta timbangan sebesar Rp 30.000 dengan persentase masingmasing alat untuk drum, baskom, pisau, kawat pemanggang serta timbangan yaitu 55,94\%, $20,98 \%, 4,89 \%, 12,59 \%$ serta $5,60 \%$.

\section{b. Biaya variabel}

Biaya variabel merupakan biaya yang habis dipakai dalam satu kali proses produksi. Dalam hal ini yang menjadi biaya variabel adalah serta biaya tenaga kerja. Untuk lebih jelasnya mengenai rata - rata biaya variabel yang dikeluarkan pengrajin dapat dilihat pada Tabel 5

Tabel 5. Rata - rata Biaya Variabel Usaha Pengolahan Ikan Lais Salai (Rp/periode)

\begin{tabular}{clcc}
\hline No & \multicolumn{1}{c}{ Uraian } & $\begin{array}{c}\text { B.variabel } \\
(\text { Rp/periode) }\end{array}$ & $\begin{array}{c}\text { Persentase } \\
(\mathbf{\%})\end{array}$ \\
\hline 1. & Ikan segar & 3.600 .000 & 66,84 \\
2. & Garam & 18.000 & 0,33 \\
3. & Kayu bakar & 280.000 & 5,20 \\
4. & Minyak tanah & 48.000 & 0,89 \\
5. & Upah tenaga & 1.440 .000 & 26,74 \\
& kerja & & \\
\hline & Jumlah & $\mathbf{5 . 3 8 6 . 0 0 0}$ & $\mathbf{1 0 0}$ \\
\hline
\end{tabular}

Berdasarkan tabel 5 di atas, biaya variabel yang dikeluarkan pengrajin dalam usaha pengolahan ikan salai adalah sebesar Rp. 5.386.000/periode produksi untuk pembelian bahan baku berupa ikan lais segar sebesar Rp 3.600.000, garam sebesar Rp 18.000, kayu bakar sebesar Rp 280.000, minyak tanah sebesar Rp 48.000 serta biaya upah tenaga kerja sebesar Rp. 1.440 .000 dengan persentase masing-masing bahan untuk ikan lais segar, garam, kayu bakar, minyak tanah dan upah tenaga kerja yaitu 66,84\%, 0,33\%, 5,20 $\%, 0,89 \%$ dan 26,74. Dapat dilihat bahwa persentase biaya variabel terbesar adalah untuk pembelian bahan baku utama yaitu ikan lais segar.

\section{c. Pendapatan dan Tingkat Keuntungan RC ratio)}

Pendapatan merupakan selisih antara penerimaan dan biaya produksi total yang terdiri dari biaya tetap dan biaya variabel. Sedangkan tingkat keuntungan (RC ratio) merupakan nisbah antara penerimaan dengan biaya produksi total. Adapun rata - rata produksi, biaya produksi total, penerimaan, pendapatan dan tingkat keuntungan usaha pengolahan ikan lais salai dapat dilihat pada Tabel 6 
Tabel 6. Rata - rata Produksi, Biaya Produksi, Penerimaan dan Pendapatan Usaha Pengolahan Ikan Lais Salai

\begin{tabular}{clc}
\hline No & \multicolumn{1}{c}{ Uraian } & Jumlah \\
\hline 1. & Produksi (Kg/periode) & 82,4 \\
2. & Harga Jual $(\mathrm{Rp} / \mathrm{kg})$ & 150.000 \\
3. & Biaya Produksi (Rp/periode) & 5.992 .260 \\
4. & Penerimaan (Rp/periode) & 12.360 .000 \\
5. & Pendapatan(Rp/periode) & 6.367 .740 \\
6. & RC ratio & 2,06 \\
\hline
\end{tabular}

Tabel 6 menginformasikan bahwa rata rata pendapatan usaha pengolahan ikan salai per periode adalah sebesar Rp. 6.367.740 dengan $\mathrm{RC}$ ratio sebesar 2,06. $\mathrm{RC}$ ratio pada usaha pengolahan ikan lais salai mempunyai nilai yang lebih besar dari satu. Hal ini berarti bahwa usaha pengolahan ikan lais salai menguntungkan.

\section{Analisis Titik Impas Usaha pengolahan \\ Ikan Lais Salai}

Analisis break even point atau analisis titik impas yang merupakan keadaan dimana total penerimaan sama dengan total biaya yang dikeluarkan selama proses produksi ikan lais salai.Perhitungan titik impas usaha pengolahan ikan lais salai dapat dilihat pada analisis di bawah ini :

a. BEP Penerimaan

$$
\begin{array}{cc}
\hline 1- & -5.992 .260 \\
\hline & 12.360 .000 \\
= & 536.260 \\
\hline & 0,52 \\
\text { Rp. } 1.013 .269,23
\end{array}
$$

b. BEP Produksi $(\mathbf{k g})=\frac{536.260}{150.0-65.364}$

$$
=6,34 \mathrm{~kg}
$$

c. BEP Harga $(\mathbf{R p} / \mathbf{k g})=\frac{5.992 .260}{82,4}$

$$
=\text { Rp. } 72.721,60 / \mathrm{kg}
$$

Dari perhitungan di atas bahwa usaha pengolahan ikan lais salai mengalami break even atau berada pada titik impas yaitu tidak mendapatkan keuntungan dan tidak menderita kerugian jika penerimaan yang diperoleh sebesar Rp.1.013.269,23/periode produksi, produksi $6,34 \mathrm{~kg} /$ periode produksiatau harga jual sebesar Rp.72.721,60 /kg.

\section{IV.KESIMPULAN DAN SARAN}

\section{a. Kesimpulan}

Berdasarkan hasil penelitian yang telah dilakukan, maka dapat diambil kesimpulan sebagai berikut :

1. Rata-rata pendapatan usaha pengolahan ikan salai/periode adalah sebesar Rp. 6.367.740 dengan $\mathrm{RC}$ ratio sebesar 2,06. $\mathrm{RC}$ ratio pada usaha pengolahan ikan lais salai mempunyai nilai yang lebih besar dari satu. Hal ini berarti bahwa usaha pengolahan ikan lais salai menguntungkan.

2. Usaha pengolahan ikan lais salai mengalami break even point atau berada pada titik impas yaitu tidak mendapatkan keuntungan dan tidak menderita kerugian jika penerimaan yang diperoleh sebesar Rp. 1.013.269,23/periode produksi, produksi $6,34 \mathrm{~kg} /$ periode produksiatau harga jual sebesar Rp. 72.721,60/kg.

\section{b. Saran}

Sebaiknya pengrajin membuat kemasan khusus untuk produk ikan lais salai agar dapat meningkatkan nilai jual produk tersebut.

\section{DAFTAR PUSTAKA}

Adawyah R. 2007. Pengolahan dan Pengawetan Ikan. Bumi Aksara. Jakarta.

Ken Suratiyah. 2015. Ilmu Usahatani. Penebar Swadaya. Jakarta.

Khairuman dan K. Amri. 2011. Pembenihan Lele 21 Hari Balik Modal. Agro Media Pustaka. Jakarta.

Moeljanto. 1992. Pengawetan dan Pengolahan Hasil Perikanan. Penebar Swadaya. Jakarta.

Soekartawi, 2001. Pengantar Agroindusri. Raja Grafindo Persada. Jakarta 